\title{
WHAT FACTORS ARE INFLUENCING MEMBERS' WILLINGNESS TO CONTRIBUTE EQUITY CAPITAL IN AGRICULTURAL COOPERATIVES?
}

\author{
Tibebu BEZABIH ${ }^{1 *}$ (D) Fekadu BEYENE ${ }^{1}$, Jema HAJI ${ }^{2}$, Tesfaye LEMMA ${ }^{1}$
}

\author{
Address: \\ ${ }^{1}$ Haramaya University, School of Rural Development and Agricultural Innovation, Ethiopia \\ ${ }^{2}$ Haramaya University, School of Agricultural Economics and Agri-Business, Ethiopia \\ * Corresponding Author's email: tibe2224@gmail.com
}

\begin{abstract}
Research background: In the current competitive agricultural market, where substantial capital investment is required to pursue growth related competitive strategies, agricultural cooperatives' performance mainly relies on members' willingness to contribute equity capital. Members are the single and most important source of investment capital.

Purpose of the article: This study investigated factors influencing members' willingness to contribute equity capital to their agricultural cooperatives in Ethiopia with the intention of providing empirical evidences to decision makers with regard to specific measures to be taken to enhance members' willingness to contribute equity capital, and thereby improve agricultural cooperatives' performance.

Methods: Multi-stage random sampling technique was employed to select the study districts, farmer associations, agricultural cooperatives and respondent households. Semi-structured questionnaire was employed to collect crosssectional data from randomly selected 214 households. The data were analysed using binary logistic regression model. Findings \& value added: We found that education level; past role as a committee member; trust on other members' commitment and directors' leadership - influence positively and significantly members' willingness to contribute equity capital. While age and perception on the cooperatives' weaknesses affect negatively and significantly members' willingness. The important policy recommendations are developing and fostering trust among members and between members and directors; re-orienting service provisions in line with the needs and interests of their members; assessing agricultural cooperatives' performance depending on the values that their members expect to obtain from membership. This study investigated the influence of trust on members' willingness to contribute equity capital, and hence will add value to better understanding of the role of trust in enhancing members' commitment in cooperative organizations. Lastly, this cross-sectional survey study subjected to limitations associated with this type of study. Hence the generalizability of its results to other areas of agricultural cooperatives needs further investigation.
\end{abstract}

Key words: agricultural cooperatives; members' willingness; equity capital contribution; binary logit; Ethiopia JEL Codes: D02, Q13, R20

\section{INTRODUCTION}

In developing countries, market participation is one of important strategy which can assist smallholder farmers to earn improved incomes, and consequently come out of poverty (Grashuis and Su, 2018; Verhofstadt and Maertens, 2014; WB, 2012). However, in these countries majority of smallholders are excluded from markets. Markets in these countries are characterized by pervasive failure. According to Adjemian et al. (2016) and Nilsson (2001), market failures are the results of a business environment generally characterized by difficult or weak contract enforcement, asymmetric information, high risks and high transaction costs. Under such business environment, individual smallholders are unlikely to participate or if so, they fail to realize the full benefits of their participation. As a result, in developing countries, collective action institutions such as agricultural cooperatives are promoted to overcome market failure and facilitate smallholder farmers' participation in modern national and international markets (Fischer and Qaim, 2012; WB, 2012).

However, since liberalization of markets through structural adjustment the competitive environment in which agricultural cooperatives operate has been changing. Withdrawal of government, removal of subsidies and the opening-up of national markets to large local and foreign business organizations have been exposing agricultural cooperatives to fierce competitions (Grashuis and Su, 2018; Benos et al., 2016; Chaddad and Iliopoulos, 2013). Hence, in order to access to and survive in the current competitive markets, agricultural cooperatives need to invest on growth related competitive strategies such as value adding and processing activities, and brand name development (Bijman et al., 2016). However, very few agricultural cooperatives are investing 
in growth strategies in developing countries. For instance, it is a common complaint among literature that many, oftentimes most, agricultural cooperatives in developing countries, including Ethiopia, have very weak investment capacity to invest in growth strategies, and hence unable to access to modern markets (Gashaw and Kibret, 2018; Amene, 2017; Hagos and Geta, 2016; Chaddad and Iliopoulos, 2013). The problem of investment capital that arise due to members' reduced willingness to contribute equity capital has often been cited as the main reason for agricultural cooperatives' weak investment capacity (Grashuis and Su, 2018; Emana et al., 2016; Delelegne et al., 2016; Mojo et al., 2016; Dejene and Regasa, 2015).In this regard, investigating factors influencing members' willingness to contribute equity capital plays important role in overcoming agricultural cooperatives' investment capital constraints.

Nevertheless, prior empirical works on the performance of agricultural cooperative and factors influencing it in Ethiopia focuses on profitability and management efficiency factors, while treating members' willingness to contribute equity capital least. For instance, according to Amene (2017) the two important factors influencing agricultural cooperatives' performance are the volume of profit generated and, the management and technical skills of board members. However, agricultural cooperatives' profit generation through efficient business management presupposes that they already have the capital for investments. But as discussed in the previous paragraph, the cooperatives' main performance problem is constraints of investment capital. Thus, it is by far better to focus on their investment capital constraints rather than focusing on profitability and management efficiency. And in agricultural cooperatives, the single most important source of investment capital is member contributed equity capital. It is therefore, paramount important to assess factors influencing members' willingness to contribute equity capital. Identifying such factors will inform decisions with regard to specific measures to be taken to enhance members' willingness, and thereby overcome agricultural cooperatives' constraints of investment capital.

However, to the best knowledge of the authors, factors influencing members' willingness to contribute equity capital are not investigated in Ethiopian agricultural cooperatives context. To fill this knowledge gap, this study investigated factors influencing members' willingness to contribute equity capital, and employed social capital and behavioural theories as its main theoretical perspective. We assume that members' willingness to contribute equity capital is a behavioural decision and influenced by various factors such as the existence of social capital (trust among members and between members and directors) and behavioural traits (attitude towards making equity capital contribution), including resource endowment (such as demographic and socio-economic characteristics).

\section{LITERATURE REVIEW}

Members' willingness can be defined as the motivation of a member to make equity capital contribution, in the form of direct investment method (besides membership fee and retained dividend or saving) for his/her cooperative's investment in growth strategies (Li et al., 2015; Nilsson, 2001). Several literatures highlighted members' willingness to contribute equity capital as the most important factor for improving agricultural cooperatives' performance (Gelo et al., 2017; Bijman et al., 2016; Kontogeorgos et al., 2014; Wang and hue, 2013; Hao, 2013; Othman et al., 2012). These authors concluded that as gaining investment capital from external sources is a costly affair, and as member contributed equity capital is the single and important option, agricultural cooperative's success highly hinges on members' willingness. Bijman et al. (2016) found that willingness of members is treated as elements for enhancing the performance of agricultural cooperatives. These authors argued that to retain members' willingness, it is crucial to know influencing factors. Hence, interventions focused on overcoming the performance problems of agricultural cooperatives shows high interest to members' willingness and its influencing factors (Gelo et al., 2017; Alho, 2016). Thus, it is imperative to investigate factors influencing members' willingness to contribute equity capital.

Various factors could influence members' willingness to contribute equity capital. Theoretical argument such as social capital theory shows the influence of trust (Putnam, 1993). In light with social capital theory, where there is trust among members and between members and directors, the likelihood of members' willingness to contribute equity capital increases (Feng et al., 2016; Valentinov, 2007). James and Sykuta (2006) and Hansen et al. (2002) empirically confirmed this theoretical argument. These authors used hierarchical regression analysis, and found a significant and positive association between members' trusts on other members' commitment and directors' leadership, and their commitment to contribute equity capital.

Another theoretical argument such as planned behaviour theory shows the influence of attitude, such as members' attitude towards making equity capital contribution (Ajzen, 1991). In light with this theory, members' positive attitude increases the likelihood of their willingness to contribute equity capital. Members' attitude in turn is the outcome of their perception on the cooperative's weaknesses. Those members who perceived the cooperative's weaknesses will develop negative attitude, and hence will have reduced willingness to contribute equity capital. Hakelius and Hansen (2016), Kontogeorgis et al. (2014) and Wang and Hue (2013) empirically confirmed this theoretical argument. These authors, using binary and ordinal logistic regression analysis respectively, found negative and significant association between members' perception on the cooperative's weaknesses and their willingness to contribute equity capital. Likewise, other behavioural theory, norm activation theory, shows the influence of awareness such as members' awareness on the need of contributing equity capital and their responsibility to make equity capital contribution (Schwartz and Howard, 1982). Members could develop such awareness through their membership status, such as through their membership duration, serving as a committee member in 
the cooperative, and participation in trainings. Azmha $\boldsymbol{e t}$ al. (2012) and Minguez - Vera et al. (2010) empirically confirmed this theoretical argument. These authors, using ordinary least square and binary logit respectively, found positive and significant association between members' membership status and their willingness to contribute equity capital.

In their respective studies, the above empirical works had controlled for the influence of demographic and socioeconomic characteristics (such as age, education, family size and access to credit). And found statistically significant influence these characteristics on members' willingness to contribute equity capital. In this study, the selection of explanatory variables was guided by the above theoretical and empirical studies.

\section{DATA AND METHODS}

\section{Description of Agricultural Cooperatives in the Study Area}

East Hararghe Zone is among the pioneer areas in Ethiopia where agricultural cooperatives flourished. However, during the military regime (1974-1991) most cooperatives were disbanded. Moreover, since 1991, under the current government, significant expansion of agricultural cooperatives has been witnessed in the East Hararghe Zone (Delelegne et al., 2016). According to the Zone's agricultural office, in 2019, there were seven unions and 1157 primary cooperatives that had 240,710 members (74,270 females and 166,440 males) in the Zone. From among the 1157 primary cooperatives, 359 were marketing, 356 were saving and credit, 379 were multipurpose, and 63 were consumer cooperatives, respectively. The information from the Zone also revealed that the unions and the primary cooperatives together had a total asset (saving) of 32,558,080 Eth. Birr (equivalent to $930,230.86$ USD; exchange rate: 1 USD = 34.99 Eth. Birr) and a capital worth 91,250,049 Eth. Birr (equivalent 2,607,144.26 USD, exchange rate: 1USD = 34.99 Eth. Birr). However, the same source further indicated that the performance of the agricultural cooperatives in the Zone is not satisfactory with regard to access to modern markets. The number of failing/quitting agricultural cooperative in the Zone was found to be relatively higher than the number in the other Zones in Oromia Regional State. This scenario made the Zone ideal for the purposes of this study and this was why East Hararghe Zone was purposefully selected for the study.

\section{Sampling Method and the Data}

Study participants (cooperative member households) were selected using multistage sampling techniques. In the first stage, five districts (Haramaya, Babile, Kombolcha, Jarso and Chelenko) were purposively selected due to the availability of a relatively high numbers of functioning agricultural cooperatives than in the other districts of the Zone. Then, after excluding kebeles with non-functioning cooperative, in the second stage, from each of the five districts, one kebele with multipurpose primary agricultural cooperatives were randomly selected. A 'kebele' is the smallest administrative unit in Ethiopia. In the third stage, from the target sample of five agricultural cooperatives (which have 1224 members), 301 sample respondents were drawn using the mathematical equation developed by Yamane (1967). The authors used the following formula to define the required sample size at $95 \%$ confidence level, degree of variability of $=0.5$ and with desired level of precision required $=0.5 \%$.

$$
n=\frac{N}{1+N(e)^{2}}
$$

Where:

$\mathrm{n}$ the sample size,

$\mathrm{N}$ the population size, and

$\mathrm{e}$ is the level of precision.

$$
n=\frac{1224}{1+1224(0.5)^{2}}
$$

$n=301$

In fourth stage, the determined sample size was distributed to each cooperative on the basis of probability proportional to size (PPS) using the following formula:

$n_{1}=\frac{n N_{1}}{N}$

Where:

$\mathrm{n}$ determined sample size

$\mathrm{N}$ target population

$\mathrm{N}_{1}$ total number of population in each cooperatives

$\mathrm{n}_{1}$ number of samples in each cooperative.

In the fifth stage, to select respondent households from the member registration lists of the five multipurpose agricultural cooperatives, a simple random sampling technique was applied. We distributed 301 questionnaires, from among which 251 questionnaires were filled and returned. Of these, 37 were dropped as they were improperly answered (filled). Thus, with $71.1 \%$ response rate, the final sample was 214 households.

In the five districts, the survey was conducted from August to November, 2019. Data were collected using a semi-structured questionnaire. After preparing the questionnaire, to check whether we included all the necessary questions in the questionnaire, we consulted key informants such as cooperative members, directors and officials working in the districts and the Zone cooperative promotion offices. These allowed us to ensure the inclusion of all the necessary questions in the questionnaire. Further, we pre-tested the questionnaire on non-sampled cooperative member households and made the necessary amendments. The questionnaire was first written in English language then translated to the Afan Oromo language spoken by the people in the region. Finally, data were collected by six enumerators who were fluent in speaking and writing the local language and well acquainted with the method of data collection.

\section{Methods of Data Analysis}

In this study, some explanatory variables such as trust (has two types: trust on other members' commitment and directors' leadership) and perception (perception on the 
cooperative's weaknesses) were not directly measured through the survey questionnaire. As a result, data analysis preceded three steps.

\section{Measuring trust}

It is difficult to measure trust directly by the survey questionnaire using one item with dichotomous response categories (yes and no). In this regard, Cummings and Bromiley (1996) suggested the use of multi-item questions with multiple response categories for measuring trust. According to these authors, using multi-item questions with multiple response categories provides a more valid as well as a more substantively detailed measurement. Former empirical study such as Feng $\boldsymbol{e t} \boldsymbol{a l}$. (2016), James and Sykuta (2006) and Hansen et al. (2002) employed multi-item questions with multiple response categories for measuring cooperative members' trust on other members' commitment and directors' leadership.

Guided by the above empirical works, in this study, we measured trust using four questions with five-point rating scale $(1=$ strongly disagree, $2=$ disagree, $3=$ neutral, $4=$ agree, and $5=$ strongly agree) in the questionnaire (see Table 1). To create single trust value, we added the values that respondents assigned to the four items (using the transform and then compute variables command; available in SPSS version 20). Then, to create two levels of trust (high and low), a composite score was computed on the added value. With four items of five response categories, a respondent can score a maximum of 20 points and a minimum of 4 points. The categorization into high and low trust was achieved using a composite score as follows: high trust category = between the mean value to maximum points, and low trust category = between the minimum points to the mean value. However, before adding and computing composite score, the four items were subjected to reliability tests using Cronbach's Alpha coefficient.

\section{Measuring perception}

Perception is difficult to measure directly by the survey questionnaire. Hence, the respondents' perception on their cooperative's weaknesses was measured via 10 multi-item questions in the questionnaire (Table 2) whose selection was guided by prior similar empirical works (Hansen $\boldsymbol{e t}$ al., 2002; Minguez - Vera et al., 2010; Othman et al., 2012; Kontogeorgeos et al., 2014; Alho, 2016) and the authors own consult with cooperative members, directors and officials working in the districts and the zone cooperative promotion offices. In the study respondents indicated their perceptions on a five point Likert scale (1 - strongly disagree, 2 - disagree, 3 - neutral, 4 - agree and 5 - strongly agree).

To determine the underlying perception variables, factor analysis was performed on the responses given by respondents to the ten multi-item questions. Factor analysis is a statistical technique for identifying the underlying perceptions (factors) measured by the ten perception questions (Field, 2005). Previous empirical studies which employed factor analysis include MinguezVera et al. (2010), Othman et al. (2012), Kontogeorgeos et al. (2014) and Alho (2016). However, before factor analysed, the ten perception questions were subjected to internal consistence and reliability tests using correlation analysis and Cronbach's Alpha coefficient respectively.

\section{Logistic regression model specification}

The dependent variable members' willingness to contribute equity capital is a dichotomous outcome variable: willing to contribute or not-willing to contribute. When the dependent variable has two nominal outcomes, like in this study, the best suiting econometric model is either Logit or Probit regression (Field, 2005). The two models (Logit and Probit) are more analogous since both models provide equally efficient parameter estimates. Despite their comparable advantages, however, Gujarati (2008) suggested the use of Logit than Probit Model when continuous independent variables are included in the model. Therefore, in this study, since the independent variables are constituted from both categorical and continuous variables Logit Model was selected. Moreover, logistic regression is a known and relatively easily understandable method for most researchers and it is implemented in all basic statistical software such as SPSS, Stata, Statistica, SAS, R, etc. (Gujarati, 2008). Prior similar empirical studies such as Kontogeorgeos et al. (2014) and Othman et al. (2012) employed logit model to determine factors influencing members' willingness to contribute equity capital.

The binary logistic regression model is a type of generalized linear model that extends the linear regression model by linking the range of real numbers to the range or probabilities $0-1$. The probability that a respondent household to be in the category of "willing to contribute" (Eq. 1).

$p[Y e s]=\frac{1}{1+e^{-\beta x}}$

Where:

$\beta$ is a vector of parameters to be estimated and $x$ is a vector of explanatory variables.

The probability that a respondent household to be in the category of "not-willing to contribute" (Eq. 2-3).

$p($ no $)=1-p($ yes $)$
$p[$ no $]=\frac{1}{1+e^{\beta x}}$

Manipulation of Equation (2) and Equation (3) gives Equation 4.

$1-p($ yes $)=\frac{1}{1+e^{\beta x}}$

$\frac{p(y e s)}{1-p(y e s)}=e^{\beta x}$

Where:

$e^{\beta x}$ is the ratio of the probability of a "willing to contribute" to the probability of a "not-willing to contribute" category. The logarithm of odds ratio is expressed as the Equations (5-6).:

$1 n\left[\frac{p(y e s)}{1-p(y e s)}\right]=\beta x$ 
WTC $=\alpha+\beta_{1}$ socio -

economic and demographic characteristics + $\beta_{2}$ membership status $+\beta_{3}$ trust +

$\beta_{4}$ perception $+\varepsilon$

Where:

$\alpha$ is intercept, WTC is willingness to contribute equity capital, socio-economic and demographic characteristics (household head's age (AGE), education level (EDU),household size (HHSIZ) and taking credit (CREDIT)), membership status(membership duration (MEMBDUR), present role as a committee member (SRVCMM), past role as a committee member (EXCMM)and participation in trainings (TRANING)), trust (trust on other members' commitments (TRUST1) and trust on directors' leadership (TRUST2)), and perception (perception on the cooperative's weakness, factor analysed (FACTOR)) and $\varepsilon$ is the error term which is logistically distributed. Explanatory variables and their expected effects are presented in Table 3.

\section{RESULTS AND DISCUSSION}

\section{Trust among Members and between Members and Directors}

Composite score was computed to create two levels for respondent households' trust. For this, we calculated the mean, maximum and minimum values on the added trust value. The mean of the whole households' trust on other members' commitment was 12.69 , the maximum value was 19 and the minimum value was 4 . Then, using these values, two levels of households' trust on other members' commitment was created. Mean value (12.69) to maximum value (19) are categorized into high trust and labelled as 1 , and minimum value (4) to mean value (12.69) are categorized into low trust and labelled as 0. The mean of the whole households' trust on directors' leadership was 12.43 , the maximum value was 20 and the minimum value was 4 . Then, using the same procedure with the above, two levels of households' trust on directors' leadership was created. Accordingly, respondent households' trust on other members' commitment (TRUST1) and directors' leadership (TRUST2) was depicted in Table 4.

Table 1: Measuring trust and reliability test

\begin{tabular}{llc} 
Variable & Item & $\begin{array}{c}\text { Cronbach's } \\
\text { Alpha }\end{array}$ \\
\hline $\begin{array}{ll}\text { Members' trust on other members' } \\
\text { commitment }\end{array}$ & $\begin{array}{l}\text { 1. Other coop. members can be trusted for being committed } \\
\text { 2. Other coop. members have a reputation for being } \\
\text { trustworthy } \\
\text { 3. Most members have no intention to cheat on other } \\
\text { members }\end{array}$ & 0.747 \\
& $\begin{array}{l}\text { 4. I trust on other members' willingness to cooperate } \\
\text { 1. Directors can be trusted for being good leaders }\end{array}$ & 0.823 \\
Members' trust on directors' & $\begin{array}{l}\text { 2. Directors have a reputation for being trustworthy } \\
\text { leadership }\end{array}$ & 3. I implicitly trust the decisions made by directors \\
& 4. Most directors have no intention to cheat members & \\
\hline
\end{tabular}

Note: All are measured with five-point rating scale: $1=$ strongly disagree, $2=$ disagree, $3=$ neutral, $4=$ agree, and $5=$ strongly agree

Source: Survey Data (2019)
As revealed in Table 4, respondent households had more trust on other members' commitment $(43.9 \%)$ than on directors' leadership $(39.7 \%)$. This implies that in agricultural cooperatives more members $(60.3 \%)$ had low trust on directors' leadership. This could be because of members' difficulty to identify the leadership capacity of directors.

\section{Factor analysis}

Factor analysis, more specifically, principal component factor analysis was computed on the ten perception questions to identify the underlying respondent households' perception on their cooperatives' weakness. Principal component analysis assumes correlation (internal consistency) between the ten perception questions, and hence the first step was deriving correlation matrix (Table 2). The correlations among the 10 perception questions were substantial, implying that they are appropriate for principal component analysis. We also checked for their reliability using Cronbach's Alpha coefficients. The acceptable value for Cronbach's Alpha coefficient is greater than or equal to 0.7 (Gujarati, 2008). The value of Cronbach's Alpha coefficient for all of the ten perception variables was greater than 0.940 , indicating that the ten items were reliable to measure households' perception and they are appropriate for factor analysis.

We further checked the adequacy of sampling for factor analysis using Kaiser-Meyer-Olkin (KMO) measure of sampling adequacy. KMO value of 0.5 is minimum (barely accepted), between 0.7-0.8 acceptable and above 0.9 are excellent. Our KMO value is 0.932 (Table 5), which indicate excellent sampling adequacy. We further checked the Bartlett's test of sphericity. Bartlett's test is another measure for the strength of the relationship among the ten perception questions. The ChiSquare result for Bartlett's test of sphericity was 1712.633 $\left(\chi^{2}(\mathrm{df} 45)=1712.633, \mathrm{p}<0.001\right)($ Table 5), which indicate strong relationship among the ten perception questions and their appropriateness for factor analysis.

Then we proceeded to factor analysis, the extraction method was principal component analysis, the number of factors to be retained was determined by eigenvalue greater than or equal to one, and the nature of relationship between factors was uncorrelated (orthogonal). The factor analysis with Kaiser Normalization and Varimax Rotation converged on two factors after three iterations. 
Table 2: Correlation Matrix

1. Weak member commitment

2. Not responding to members' demand

3. Decreasing membership

4. Weak control over members

5. Weak market linkage

6. Inability to provide inputs on the right time

7. Biased credit provision

8. Difficulty to know about directors' actions

9. Poor extension service provisions

10. Members' poor participation in general assembly

Note: ${ }^{* *}$ Correlation is significant at 0.01 level (2-tailed).

7

Table 3: Explanatory variables, acronyms, measurement and prior expected influence

Variable Acronym

Measurement (anticipated influence)

Socio-demographic characteristics

Household head's age

AGE In number of years (-)

Household head's education level

Household size

Taking credit

Number of years attended in formal edu. $(+)$

Membership status variables

Membership duration

Present role as a committee member

Past role as a committee member

HHSIZ Number of persons living in the $\mathrm{HH}(+)$

CREDIT 1 for Yes, 0 otherwise $(+)$

MEMBDUR Number of years in the cooperative

SRVCMM 1 for Yes, 0 otherwise (+)

EXCMM 1 for Yes, 0 otherwise $(+)$

Participation in trainings

TRANING 1 for Yes, 0 otherwise (+)

Trust variables

Trust on other members' commitment TRUST1 1 for Yes, 0 otherwise $(+)$

Trust on directors' leadership

TRUST2 1 for Yes, 0 otherwise $(+)$

Perception variables

Perception on the coop. weaknesses FACTOR Factor analysed (-)

Source: Survey data (2019) 
Table 4: Members' trust on other members' commitment and directors' leadership

\begin{tabular}{lrrrrr}
\hline Trust type & Trust level & Frequency & Percent & Overall mean & Overall Std. Dev. \\
\hline TRUST1 & Low & 120 & 56.1 & 1.44 & 0.50 \\
& High & 94 & 43.9 & & \\
& Total & 214 & 100.0 & & 0.49 \\
TRUST2 & Low & 129 & 60.3 & 1.41 & \\
& High & 85 & 39.7 & & \\
& Total & 214 & 100.0 & & \\
\hline
\end{tabular}

Source: Survey Data (2019)

Table 5: Factor analysis on perception variables

\begin{tabular}{|c|c|c|c|}
\hline \multirow[t]{2}{*}{ Variable } & \multirow[t]{2}{*}{ Communalities } & \multicolumn{2}{|c|}{ Factor loading after Varimax } \\
\hline & & Factor1 & \\
\hline 1. Weak member commitment & 0.737 & 0.795 & \\
\hline 2. Not responding to members' demand & 0.728 & & 0.615 \\
\hline 3. Decreasing membership & 0.789 & 0.784 & \\
\hline 4. Weak control over members & 0.789 & 0.853 & \\
\hline 5. Weak market linkage & 0.711 & & 0.803 \\
\hline 6. Inability to provide inputs on the right time & 0.853 & & 0.873 \\
\hline 7. Biased credit provision & 0.709 & 0.632 & \\
\hline 8. Difficulty to know about directors' actions & 0.840 & & 0.865 \\
\hline 9. Poor extension service provisions & 0.823 & 0.863 & \\
\hline 10. Members' poor participation in general assembly & 0.603 & & 0.667 \\
\hline Eigenvalue & & 6.544 & 1.039 \\
\hline Variance explained & & 65.436 & 10.383 \\
\hline Total variance explained & & 75.822 & \\
\hline KMO measure of sampling adequacy & & 0.932 & \\
\hline Bartlett's test of Sphericity & & $\chi^{2}(\mathrm{df} 45)=1712$ & 0.001 \\
\hline
\end{tabular}

Note: Extraction Method: Principal Component Analysis.

Rotation Method: Varimax with Kaiser Normalization.

Rotation Converged in 3 iterations.

Source: Survey data (2019).

The first factor was named as poor extension service provision (FACTOR1) and the second factor was named as inability to provide inputs on the right time (FACTOR2) (the names are arbitrary, taken from the item which has the highest correlation coefficient in each factor). The detail about the ten perception variables, communalities $\left(\mathrm{R}^{2}\right)$, factor loadings and the emerged two factors are depicted in Table 5.

We observed in Table 5 that the first factor (FACTOR1) has emerged as the highest households' perception on the cooperatives' weaknesses, explaining $65.44 \%$. Under this factor, five measures (poor extension service provisions, weak control over members, weak members' commitment, decreasing membership and biased credit service provision) were converted into one factor. The second factor (FACTOR2) has emerged as the second highest households' perception on the cooperatives' weaknesses, explaining $10.38 \%$. Under this factor, five measures (inability to provide inputs on time, difficulty to know about directors' actions, weak market linkage, members' poor participation in general assembly and not responding to members' demands) were converted into one factor.

To create two uncorrelated perception scale scores and use them in the logistic analysis, first, we tested for the reliability of the two factors. The Cronbach's Alpha values for the first and second factors were 0.917 and 0.906 respectively, which are acceptable. Then, we set factor scores to be calculated and saved on the data set using Anderson - Rubin method (available in SPSS version 20). Accordingly, the factors of each variable were transformed into two factor scores (FACTOR1 and FACTOR2, with mean $=0 \mathrm{E}-7$ and standard deviation $=$ 1.00) by Anderson - Rubin method. Nevertheless, when we checked correlation, the two factor scores had high correlation. Hence, it was unnecessary to use both in the regression analysis. As a result, we selected FACTOR1 for the logistic analysis, this was because FACTOR1 explained the highest variation in respondent households' perception on the cooperatives' weaknesses than FACTOR2 (see Table 5).

\section{Agricultural cooperatives' weaknesses as perceived by their members}

We also generated simple descriptive statistics to summarize the univariate distributions of the rates for each of the ten items, which revealed the prevailing weaknesses of agricultural cooperatives as perceived by respondent households (Table 6).

As shown in Table 6, the means for each of the items appear to be reasonable as each of the items is measured on a 5 - point Likert Scale. No values are above 5 or below 1. The standard deviations did not vary a lot, suggesting that there are no outliers for any of the items. Based on the rating of the last two response categories (Agree and Strongly Agree), the result shows that cooperative's weakness related to market linkage was the highest rated item. The implication is that agricultural cooperatives in 
the study area were weak with respect to market linkage. The second highly rated item was difficulty of knowing about directors' actions. The implication is that it was difficult for members to know about their directors' actions in the study area of agricultural cooperatives. The result in Table 6 also shows that the third highly rated item was cooperatives' inability to provide inputs on the right time. The implication is that agricultural cooperatives in the study area were weak with regard to supplying inputs on the right time. In a situation of climate change, in an unpredictable weather conditions, inability to obtain inputs on the right time could have many devastating effects on member farmers, such as exposure to risks related to climate change. Exposure for such risks in turn affects their level of production and profitability. Our result is consistent with the results reported by Amene (2017) and Dejene and Regasa (2015). These authors in their results reported agricultural cooperatives' weaknesses with regard to market linkage and input supply on the right-time.

\section{Descriptive analysis}

We also computed independent sample t-test on continuous explanatory variables to look at mean difference between willing and not-willing households, and cross-tabulation to look at associations between categorical explanatory variables and the outcome variable. Table 7 and Table 8 show the results of the independent sample t-test and the cross-tabulation respectively.

Independent sample t-test of households' willingness for each of the continuous explanatory variables is shown in Table 7. Compared to non-willing household heads, willing household heads were younger in age. The t-test for equality of means is statistically significant at $1 \%$ level of significance. Indicating that, there are differences between willing and not-willing households with respect to the age of the household heads (AGE). The t-test has a negative sign, implying that compared to elder household heads, younger household heads were more willing to contribute equity capital.

Formal education (EDU) is deemed to enhance one's ability to compare the advantages and disadvantages of investment, and quickly reach a decision, like decision on equity capital contribution. If this is the case members' willingness could vary depending on their level of formal education. In our result the t-test is significant at less than $1 \%$ significance level, indicating that there is a difference between willing and not-willing households that could be explained by the household head's formal education level. The t-test has a positive sign, indicates that formal education increases willingness. The insignificant t-test result for household size (HHSIZ) implies that there is no difference between willing and non-willing households with respect to their household size. Likewise, there is no difference between willing and non-willing households with respect to their membership duration (MEMBDUR) in agricultural cooperatives.

Members are less likely to contribute equity capital once after they perceived their cooperative's weaknesses. As shown in Table 7, not-willing households than willing household perceived more on the cooperative's weaknesses (FACTOR1). The t-test revealed a significant result, indicating that there is a difference between willing and not-willing households with respect to their perception on the cooperative's weakness. It has a negative sign, indicating that perception on FACTOR1 decreases households' willingness to contribute equity capital.

Cross tabulations of willingness by each of the categorical explanatory variables is shown in Table 8 . As the result shows, with regard to taking credit (CREDIT), the proportion of willingness to contribute equity capital was highest among households who took credit (while $59.52 \%$ ( 50 out of 84 ) of households who took credit were willing, only $41.54 \%$ (54 out of 130) of households who did not take credit were willing). The chi-square test of association at 6.608 is significant $(\mathrm{p}<0.05)$, implying that there is an association between households taking credit and their willingness to contribute equity capital.

With respect to present role as a committee member in the cooperative (SRVCMM), the proportion of willingness was highest among households who have present role. As seen in the result, while $62.12 \%$ of households with present role as a committee member were willing, only $42.57 \%$ of households without present role as a committee member were willing. The chi-square test of association at 6.986 is significant $(p<0.05)$, implying that there is association between households' present role as a committee member and their willingness to contribute equity capital. Similarly, the proportion of willingness increases for households who have past role as a committee member (EXCMM). The chi-square test of association at 66.988 is highly significant ( $p<0.001$ ), implying that households' past role as a committee member and their willingness have association. However, with respect to participation in trainings (TRANING) the chi-square test of association revealed insignificant result, implying that households' participation in trainings is not associated with their willingness to contribute equity capital.

The existence of trust among members, and between members and directors is a sign of reduced opportunistic behaviour both from members as well as directors. Such scenario is more likely to enhance members' willingness to contribute equity capital. With respect to trust on other members' commitment (TRUST1), as shown in Table 8, the proportion of willingness was highest among households who have trust on other members' commitment. While $82.98 \%$ of households who have trust on other members' commitment were willing, only $21.67 \%$ of households who do not trust on other members' commitment were willing. The chi-square test of association at 79.321 is highly significant ( $p<0.001)$, implying that there is an association between households' trust on other members' commitment and their willingness to contribute equity capital. Similarly, the proportion of willingness increases for households who have trust on directors' leadership (TRUST2). The chi-square test of association at 101.435 is highly significant ( $p<0.001$ ), implying that households' trust on directors' leadership and their willingness to contribute equity capital have association. 
To sum up, in the descriptive analysis we observed that most of our explanatory variables, except household size (HHSIZ), membership duration (MEMBDUR), and participation in trainings (TRANING), have statistically significant results. Hence, except HHSIZ, MEMBDUR and TRANING all the explanatory variables were selected for further analysis in the logistic regression model.

\section{Factors Influencing Members' Willingness to Contribute Equity Capital}

Before running the model, we first tested for its effectiveness. The model adequately fits our data set (Omnibus Test of Model Coefficient was $\chi^{2}(8)=249.020$, $\mathrm{p}<0.001$, and Hosmer and Lemeshow test static was 5.749; $\left(\chi^{2}(8)=0.194, \mathrm{p}=0.675\right)$. The model accurately predicts the outcomes for each case $(-2 \log$ likelihood $=$ 47.479). The $-2 \log$ likelihood or the deviance is a measure of how much unexplained variation exists in our logistic regression model. Accordingly, low value indicates low variation, and hence high accuracy of the model. The model explained $91.7 \%$ of the variances (Nagelkerk $\mathrm{R}^{2}=$ 0.917). Table 9 shows the results of the logistic regression using the enter method.

The logistic regression results in Table 9 show that from among the eight explanatory variables, six variables had statistically significant influence on households' willingness to contribute equity capital. These explanatory variables include age (AGE), education (EDU), past role as a committee member (EXCMM), trust on other members' commitment (TRUST1), trust on directors' leadership (TRUST2), and perception on the cooperative's weakness (FACTOR1).

Household heads' age (AGE) negatively influenced willingness to contribute equity capital at less than 1 percent level of significance. The negative significant coefficient of age indicates that increase in household heads' age is associated with decreasing odds ratio of willingness to contribute equity capital. The Exp (B) column (the odds ratio) indicates that a unit increases in household heads' age by one year, decreases the likelihood of willingness to contribute equity capital by 0.749 units. This implies that compared to elderly household heads, young household heads had more likelihood of willingness to contribute equity capital. This result is contrary to the result reported by Othman et al. (2012). These authors indicate a positive and significant influence of household heads' age on their willingness to contribute equity capital. One possible reason for our contrary result could be the time restriction put on members' residual income rights (benefit earning). In agricultural cooperatives members are allowed to earn benefit from their investments only during their membership periods. As a result, old age members may not earn the full benefits of their invested assets, and hence likely to have reduced willingness to contribute equity capital.

Household heads' education level (EDU), years spent in formal education, positively influenced willingness to contribute equity capital at less than 5 percent level of significance. The positive significant coefficient of education indicates that increase in household heads' formal education level is associated with increasing odds ratio of willingness to contribute equity capital. A unit increases in household heads' education level by one year, increases the likelihood of willingness to contribute equity capital by 1.290 unit. This implies that household heads with more formal education had more likelihood of willingness to contribute equity capital than household heads with less formal education. This result is similar with Kontogeorgeos et al. (2014) who in their result indicate a significant and positive influence of household heads' education level on their willingness to contribute equity capital.

From among membership status, past role as a committee member (EXCMM) positively influenced willingness to contribute equity capital at less than 5 percent level of significance. Compared to households who responded no to past role as a committee member (the reference categories), the odds of willingness to contribute equity capital was 16.352 times higher for households who responded yes to past role as a committee member. This result is parallel with Minguez - Vera et al. (2010) and Azmha et al. (2012). These authors in their results indicate positive and significant influence of past role as a director on members' willingness to contribute equity capital.

Table 6: Descriptive statistics on the ten perception variables (No. 214)

\begin{tabular}{lrrrrrrr}
\hline Variables & Mean & Std. Dev. & \multicolumn{2}{c}{ Response categories } & & \\
& & & SD & D & N & A & SA \\
\hline 1. Weak member commitment & 2.785 & 1.237 & 28 & 89 & 16 & 63 \\
2. Not responding to members' demand & 2.991 & 1.237 & 18 & 84 & 20 & 66 & 26 \\
3. Decreasing membership & 2.822 & 1.145 & 21 & 89 & 21 & 73 & 10 \\
4. Weak control over members & 2.785 & 1.241 & 29 & 89 & 11 & 69 & 16 \\
5. Weak market linkage & 3.537 & 1.120 & 6 & 42 & 44 & 75 & 47 \\
6. Inability to provide inputs on the right & 3.252 & 1.172 & 13 & 56 & 40 & 74 & 31 \\
time & & & & & & & \\
7. Biased credit provision & 3.108 & 1.412 & 27 & 71 & 18 & 48 & 50 \\
8. Difficulty to know about directors' actions & 3.393 & 1.128 & 10 & 48 & 36 & 88 & 32 \\
9. Poor extension service provisions & 2.458 & 1.309 & 60 & 79 & 5 & 57 & 13 \\
10. Members' poor participation in general & 3.005 & 1.028 & 11 & 69 & 52 & 72 & 10
\end{tabular}
assembly

Note: SD = Strongly Disagree, D = Disagree, $\mathrm{N}=$ Neutral, A = Agree, and SA = Strongly Agree Source: Survey data (2019). 
Table 7: Independent sample t-test for continuous explanatory variables

\begin{tabular}{|c|c|c|c|c|c|c|c|}
\hline \multirow[t]{2}{*}{ Variable } & \multicolumn{2}{|l|}{ WTC (104) } & \multicolumn{2}{|l|}{ Not-WTC (110) } & \multicolumn{2}{|l|}{ Total (214) } & \multirow[t]{2}{*}{ t-test } \\
\hline & Mean & SD & Mean & & Mean & SD & \\
\hline$\overline{\mathrm{AGE}}$ & 27.89 & 3.75 & 34.41 & 4.63 & 33.48 & 7.72 & $-11.265^{* * * *}$ \\
\hline EDU & 9.75 & 1.83 & 4.82 & 3.13 & 6.58 & 3.49 & $13.983^{* * *}$ \\
\hline HHSIZ & 6.13 & 2.37 & 6.52 & 2.38 & 6.29 & 2.23 & -1.180 \\
\hline MEMBDUR & 6.26 & 3.56 & 6.08 & 4.34 & 6.17 & 3.97 & 0.327 \\
\hline FACTOR1 & -0.65 & 0.49 & 0.61 & 0.98 & 0E-7 & 1.000 & $-11.850^{* * * *}$ \\
\hline
\end{tabular}

Source: Survey data (2019).

Table 8: Cross-tabulation for categorical explanatory variables

\begin{tabular}{llrrrr}
\hline Variable & Resp. & WTC (104) & Not-WTC (110) & Total & Pearson $\chi^{2}$ value \\
\hline CREDIT & No & 54 & 76 & 130 & $6.608^{* *}$ \\
& Yes & 50 & 34 & 84 & \\
& Total & 104 & 110 & 214 & \\
SRVCMM & No & 63 & 85 & 148 & $6.986^{* *}$ \\
& Yes & 41 & 25 & 66 & \\
& Total & 104 & 110 & 214 & \\
EXCMM & No & 39 & 100 & 139 & $66.988^{* * *}$ \\
& Yes & 65 & 10 & 75 & \\
& Total & 104 & 110 & 214 & \\
TRANING & No & 58 & 49 & 107 & 2.694 \\
& Yes & 46 & 61 & 107 & \\
& Total & 104 & 110 & 214 & \\
TRUST1 & No & 26 & 94 & 120 & $79.321^{* * *}$ \\
& Yes & 78 & 16 & 94 & \\
& Total & 104 & 110 & 214 & \\
TRUST2 & No & 25 & 101 & 126 & $101.435^{* * *}$ \\
& Yes & 79 & 9 & 88 & \\
& Total & 104 & 110 & 214 & \\
\hline
\end{tabular}

Source: Survey data (2019).

Table 9: Factors influencing members' willingness to contribute equity capital

\begin{tabular}{|c|c|c|c|c|c|}
\hline Variable & $\mathrm{B}$ & SE & Wald & P-Value & $\operatorname{Exp}(B)$ \\
\hline \multicolumn{6}{|l|}{ Step $1^{a}$} \\
\hline AGE & -0.289 & 0.089 & 10.499 & 0.001 & 0.749 \\
\hline EDU & 0.254 & 0.145 & 3.083 & 0.079 & 1.290 \\
\hline CREDIT(1) & -0.921 & 0.897 & 1.052 & 0.305 & 0.398 \\
\hline SRVCMM(1) & 1.792 & 1.275 & 1.976 & 0.160 & 6.000 \\
\hline $\operatorname{EXCMM}(1)$ & 2.794 & 1.238 & 5.092 & 0.024 & 16.352 \\
\hline TRUST1(1) & 1.635 & 0.836 & 3.823 & 0.051 & 5.127 \\
\hline TRUST2(1) & 3.184 & 0.861 & 13.662 & 0.000 & 24.134 \\
\hline FACTOR1 & -2.184 & 0.613 & 12.706 & 0.000 & 0.113 \\
\hline Constant & 2.963 & 3.489 & 0.721 & 0.396 & 19.348 \\
\hline
\end{tabular}

Note: a. Variable(s) entered on step 1: AGE. EDU, CREDIT, SRVCMM, EXCMM, TRUST1, TRUST2, FACTOR1

Source: Survey data (2019)

The two trust variables, TRUST1 (trust on other members' commitment) and TRUST2 (trust on directors' leadership), positively influenced members' willingness to contribute equity capital at less than 5 and 1 percent level of significance respectively. The positive significant coefficients of TRUST1 and TRUST2 indicate that trusts on other members' commitment and directors' leadership increases the likelihood of willingness to contribute equity capital. Willingness to contribute equity capital 5.127 and 24.134 times favoured by households who had trusts on other members' commitment and directors' leadership respectively, taking those households who do not trust on other members' commitment and directors' leadership as the reference groups. This is consistent with James and Sykuta (2006) and Hanson et al. (2002). These authors indicate positive and significant influence of trust on other members' commitment and directors' leadership on members' willingness to contribute equity capital.

Finally, as depicted in Table 9, perception on the cooperatives' weakness (FACTOR1) negatively influenced willingness to contribute equity capital at less than 1 percent level of significance. The negative significant coefficient of FACTOR1 indicates that perception on the cooperatives' weaknesses decrease the likelihood of willingness to contribute equity capital. Willingness to contribute equity capital was 0.113 times not favoured by households who had perceived on FACTOR1, taking those households who did not perceive on FACTOR1 as the reference group. This result is consistent with Hakelius and Hansen (2016), 
Kontogeorgeos et al. (2014) and Wang and Hue (2013). These authors indicate negative and significant association between members' perception on the cooperative's weaknesses and their willingness to contribute equity capital.

However, in this study, we did not find statistically significant association between households' taking credit (CREDIT) and present role as a committee member (SRVCMM), and their willingness to contribute equity capital. The implication is that members' taking credit and present role as a committee member had no role on their willingness to contribute equity capital.

\section{CONCLUSION AND RECOMMENDATION}

The result showed that, agricultural cooperatives were weak with respect to market linkage, informing members about directors' actions, and inputs supply on the right time. The result also showed that more than half $(51.4 \%)$ of households were not-willing to contribute equity capital for their agricultural cooperatives' investment in growth activities. This could be because of these members' negative attitude towards making equity capital contribution due to their perception on the above weaknesses of their agricultural cooperatives. The implication is that cooperatives should attend to the service needs and interests of their members and assess their performance depending on, among others, the values that their members perceive to obtain from the membership.

The result also showed that members' trust on other members' commitment and directors' leadership had a positive influence on their willingness to contribute equity capital. The implication is that cooperatives should develop and foster trust among members and between members and directors. To develop trust among members, it is recommended to implement activities that facilitate social interactions and mutual-supports among members. To develop members' trust on directors' leadership, it is recommended to enhance directors' leadership abilities through training, workshops and seminars. These in turn enhances members' willingness to contribute equity capital.

Moreover, the result showed that past role as a committee member significantly and positively influenced households' willingness to make equity capital contribution. This could be because of through serving as a committee member or involving in roles related to committee households are developing a sense of ownership, and that in turn enhance their willingness to contribute. Thus, it is recommended to increase the number of committee members in the board of directors so that more members could get opportunity to assume a role in board committee member.

Furthermore, in the result as education is positively influencing members' willingness to make equity capital contribution, it necessitates educating members through training, workshops and seminars. Such education should focus on the advantages that members could obtain with their cooperative's investment on growth activities. In doing so, members' awareness about the advantages of cooperative's investment for the betterment of their incomes is enhanced. This in turn will enhance members' willingness to make equity capital contribution.

Based on the above, the study concludes that social capital theory and the two behavioural theories (planned behaviour and norm activation model) provides important framework to explain members' willingness to contribute equity capital in agricultural cooperatives.

Finally, this cross-sectional study is subjected to limitations inherent in this type of research. The study's focuses on one geographic location with specific institutional culture may limit the generalizability of its results to all agricultural cooperatives. Further research is needed to help determine if the results in this study are valid to all agricultural cooperatives.

Acknowledgments: We are grateful to officials working in East Harerghe zone and the five districts, and to cooperative members and directors for their time spent during the survey.

\section{REFERENCES}

ADJEMIAN, M. K., BRORSEN, B. W., HAHN, W., SAITONE, T. L., \& SEXTON, R. J. (2016). Thinning Markets in U.S. Agriculture. Economic Information Bulletin No. 148. U.S. Department of Agriculture, Economic Research Service, Washington, DC

AJZEN, I. (1991). The theory of planned behavior. Organizational behavior and human decision processes, $\quad 50(2), \quad 179 \quad-\quad$ 211, http://doi.org/10.1016/0749-5978(91)90020-T

ALHO, E. (2016). Survey Evidences of members' willingness to invest in agricultural hybrid cooperatives. Journal of Chain and Network Science. 16(1): 41-58, http://doi.org/10.3920/JCNS2014.0006

AMENE, T. B. (2017). Assessment of factors affecting performance of agricultural cooperatives in wheat market: The case of Gedeb Hasasa District, Ethiopia. African Journal of Business Management, 11(16), pp. 393-414, http://doi.org/10.5897/AJBM2017.8293

BENOS, T., KALOGERAS, N., VERHEES, F. J., SERGAKI, P., \& PENNINGS, J. M. (2016). Cooperatives' organizational restructuring, strategic attributes, and performance: The case of agribusiness cooperatives in Greece. Agribusiness, 32(1): 127-150, https://doi.org/10.1002/agr.21429

BIJMAN, J., MURADIAN, R., \& SCHUURMAN J. (Eds.) (2016). Cooperatives, economic democratization and rural development. Edward Elgar UK: Cheltenham.

CHADDAD, F., \& ILIOPOULOS, C. (2013). Control rights, governance, and the costs of ownership in agricultural cooperatives. Agribusiness, 29(1), 3-22, http://doi.org/10.1002/agr.21328.

CUMMINGS, L. L., \& BROMILEY, P. (1996). The organizational trust inventory (OTI): Development and validation. In Kramer, R. \& Tyler, T. (Eds), Trust in organization. Thousands Oaks, CA: Sage.

DEJENE, E., \& REGASA, D. G. (2015). Factors affecting success of agricultural marketing cooperatives in Becho Woreda, Oromia Regional State of Ethiopia. 
International Journal of Cooperative Studies, 4(1): 917, http://doi.org/10.11634/216826311504630

DELELEGNE, T., BIJMAN, J., \& SLINGERLAND, M. (2016). Agricultural cooperatives in Ethiopia: evolution, functions and impact. Journal of International http://doi.org/10.1002/jid.3240

EMANA, B., KETEMA, M., MUTIMBA, J. K., \&, JEMAL YOUSUF, J. (2016). Factors affecting market outlet choice of potato producers in Eastern Harerghe Zone, Ethiopia. Journal of Economics and Sustainable Development, $\quad 6(15): \quad 159 \quad$ - $\quad 160$, http://www.iiste.org/Journals/index.php/JEDS/article/ view/25288. Accessed on 6 June 2020.

FENG, L., FRIIS, A., \& NILSSON, J. (2016). Social capital among members in grain marketing cooperatives of different sizes. Agribusiness, 32(1): 113-126, https://doi.org/10.1002/agr.21427

FIELD, A. (2005). Discovering statistics using SPSS. London: SAGE Publication

FISCHER, E., \& QAIM, M. (2012). Linking smallholders to markets: Determinants and impacts of farmer collective action in Kenya. World Development, 40(6): 1255-1268, https://doi.org/10.1016/j.worlddev.2011.11.018

GASHAW, B. A., \& KIBRET, S. M. (2018). Factors influencing farmers' membership preferences in agricultural cooperatives in Ethiopia. American Journal of Rural Development, 6(3): 94-103, doi: 10.12691/ajrd-6-3-4

GELO, D., MUCHAPONDWA, E., \& ABEBE, S. (2017). Return to investment in agricultural cooperatives in Ethiopia. Working Paper Series. No. 288. African Development Bank Group.

GRASHUIS, J., \& Su, Y. (2018). A review of the empirical literature on farmer cooperatives: Performance, ownership and governance, finance, and member attitude. Annals of Public and Cooperative Economics, 90(1): 77-102, https://doi.org/10.1111/apce.12205

GUJARATI, D. N. (2008). Basic Econometrics. 5th edition. McGraw Hill/Irwin: New York.

HAGOS, A., \& GETA, E. (2016). Review of smallholder agricultural commercialization in Ethiopia: What are the deriving factors to focus on? Journal of Development and Agricultural Economics, 8(4): 6576, http://doi.org/10.5897/JDAE2016.0718

HAKELIUS, K., \& H., HANSEN. (2016). Measuring changes in farmers' attitudes to agricultural cooperatives: Evidence from Swedish agriculture 1993-2013. Agribusiness, 32(4): 531-546, https://doi.org/10.1002/agr.21464

HANSON, M. H., MORROW, J. L, \& BATISTA, J.C. (2002). The impact of trust on cooperative membership retention, performance, and satisfaction. An exploratory study. International Food and Agriculture Management Reviews, 5(1), 41-59, http://doi.org/10.22004/ag.econ.34587

HAO, Z. (2013). How does debt capital affect members' commitment in agricultural cooperatives: A case studies of Chinese agricultural cooperatives. Online Publication: http://stud.epsilon.slu.se
JAMES, H., \& SYKUTA, M. E. (2006). Farmer trust in producer-and investor-owned firms: Evidence from Missouri corn and soybean producers. Agribusiness, 22(1): 135-153, https://doi.org/10.1002/agr.20069

KONTOGEORGOS, A., CHATZITHEODORIDIS, F., \&THEODOSSIOU, G. (2014). Willingness to invest in agricultural cooperatives: Evidence from Greece. Journal of Rural Cooperation, 42(2): 122-138, http://doi.org/10.22004/ag.econ.249775

LI, Z., JACOBS, K. L., \& ARTZ, G. M. (2015). The cooperative capital constraint revisited. Agricultural Finance Review, 75(2): 253-266, https://doi.org/10.1108/AFR-11-2014-0034

MINGUEZ-VERA, A., MARTIN-UGEDO, J. F., \& ARCAS-LARIO, N. (2010). Agency and property rights theories in agricultural cooperatives: Evidence from Spain. Spanish Journal of Agricultural Research, 8(4): 908-924, http://doi.org/10.5424/sjar/2010084-1384

MOJO, D., FISHER, CH., \&DEGEFA, T. (2016). The determinants and economic impacts of membership in coffee farmer cooperatives: recent evidence from rural Ethiopia. Journal of Rural Studies, 50. 83-94, http://dx.doi.org/10.1016/j.jrurstud.2016.12.010.

NILSSON, J. (2001). Organizational principles for cooperative firms. Scandinavian Journal of Management, 17: 329-356, http://doi.org/10.1016/S0956-5221(01)00010-0

OTHMAN, A., KARI, F, JANI, R, \& HAMDAN, R. (2012). Factors influencing cooperative membership and share increment: an application of the logistic regression analysis in the Malaysian cooperatives. World Reviews of Business Research

PUTNAM, R. (1993). The prosperous community: social capital and public life. The American Prospect, 13-35.

SCHWARTZ, S. H., \& HOWARD, J. (1982). Helping and cooperation: A self-based motivational model. In V. Derlega \& J. Grzelak (Eds.) Cooperation and helping behavior. New York: Academic press.

VALENTINOV, V. (2007). Why are cooperatives important in agriculture? An organizational economics perspective. Journal of Institutional Economics, 3(1): 55-69, http://doi.org/10.1017/S1744137406000555

VERHOFSTADT, E., \& MAERTENS, M. (2014). Smallholder cooperatives and agricultural performance in Rwanda: Do organizational differences matter?'. Agricultural Economics, 45(S1): 39-52, https://doi.org/10.1111/agec.12128

WANG, L., \& HUE, X. (2013). Member investment willingness in agricultural cooperatives in Shaanxi (China). Journal of Rural Cooperation. 39(2): 176198, http://doi.org/10.22004/ag.econ.249698

WORLD BANK. (2012). Social capital for development. www.worldbank.org/poverty/scapital Accessed on 22 July 2020.

YAMANE, T. (1967). Statistics: an introductory analysis. 2nd Edition. New York: Harper \& Row Publishers. 